\title{
A modified cows' milk formula suitable for low birthweight infants
}

\author{
T J FRENCH, M COLBECK, D BURMAN, B D SPEIDEL, AND R A HENDEY \\ Department of Paediatrics, Bristol Maternity Hospital; Cow and Gate, Trowbridge, Wilts
}

SUMMARY Low birthweight babies fed standard modified cows' milk formulae are at risk from the high fluid intake needed for adequate nutrition, and very preterm babies often develop late hyponatraemia if the sodium intake fails to match large renal losses. A new cows' milk formula (Cow and Gate Prematalac) provides $120 \mathrm{kcal}, 3.6 \mathrm{~g}$ protein, $7.5 \mathrm{~g}$ fat, and $4 \mathrm{mmol}$ sodium in $150 \mathrm{ml}$. Ten low birthweight babies were fed the new formula at $150 \mathrm{ml} / \mathrm{kg}$ a day and compared with 12 similar babies fed a standard modified cows' milk formula (Wyeth SMA Gold Cap) at $180 \mathrm{ml} / \mathrm{kg}$ a day. All the babies grew at intrauterine rates and there was no difference in clinical course. None fed the new formula developed hypernatraemia, oedema, or dehydration and none fed the standard formula developed hyponatraemia. The Prematalac group safely excreted the increased osmotic load and had a higher urinary sodium concentration which should protect less mature preterm infants from late hyponatraemia.

In the UK most preterm infants are fed their mother's milk, banked breast milk, or milk formulae. These formulae contain $67 \mathrm{kcal} / 100 \mathrm{ml}$ and have a low sodium concentration to suit the needs of term infants. ${ }^{1}$ In the 3 rd trimester the fetus gains weight at about twice the rate of a term infant in early postnatal life, and major changes take place in body composition as organs develop and stores of energy and minerals accumulate. ${ }^{2}$ It is debatable whether the extrauterine growth rate of the preterm infant needs to match the intrauterine growth rate but such comparison is widely considered a yardstick of the growth and development that are taking place in the central nervous system.

Intrauterine growth rates can be achieved in preterm infants fed breast milk or milk formulae if an amount of $110-150 \mathrm{kcal} / \mathrm{kg}$ a day is given, ${ }^{3}$ but high fluid intakes are required which may lead to a poor tolerance of feed, or to an increased incidence of patent ductus arteriosus ${ }^{4}$ and necrotising enterocolitis. ${ }^{5}$ In addition late hyponatraemia may occur in the very low birthweight baby in whom renal handling of sodium is less developed than in the more mature infant. ${ }^{67} \mathrm{~A}$ sodium intake of $3 \mathrm{mmol} /$ $\mathrm{kg}$ a day prevents hyponatraemia in very low birthweight babies who are well ${ }^{6}$ but sick preterm infants have greater sodium losses and require higher intakes. ${ }^{8}$

We have devised a cows' milk formula with a higher energy, protein, and sodium content than in standard formulae and have fed it at $150 \mathrm{ml} / \mathrm{kg}$ a day to low birthweight infants. Growth rates and clinical and metabolic data were compared with those of a similar group fed a standard milk formula at $\mathbf{1 8 0}$ $\mathrm{ml} / \mathrm{kg}$ a day.

\section{Patients and methods}

Newborn babies weighing less than $2500 \mathrm{~g}$ entered the trial provided they were not multiple births, large for gestational age, had major congenital abnormalities, or were babies of mothers wishing to breast feed. At birth each baby was placed in one of two groups so that the distribution of birthweights and the proportion of small for gestational age babies in each group were similar. A baby was regarded to be large or small for gestational age if the birthweight was above the 90th centile or less than the 10th centile for gestational age on Gairdner and Pearson growth and development charts. ${ }^{9}$ One group was allocated the new milk (Cow and Gate Prematalac) at a volume of $150 \mathrm{ml} / \mathrm{kg}$ a day; the other was given Wyeth SMA Gold Cap at 180 $\mathrm{ml} / \mathrm{kg}$ a day. The composition of the milks and intakes on full feeding are shown in Table 1. The osmolalities of Cow and Gate Prematalac and Wyeth SMA Gold Cap are 342 and $300 \mathrm{mmol} / \mathrm{kg}$ respectively. Feeding began when clinically indicated and infants entered the trial after full oral feeding had been established. None received phototherapy, 
Table 1 Composition of milks and intakes of full feeds

\begin{tabular}{|c|c|c|c|c|}
\hline & \multicolumn{2}{|c|}{$\begin{array}{l}\text { Cow and Gate } \\
\text { Prematalac }\end{array}$} & \multicolumn{2}{|c|}{ SMA Gold Cap } \\
\hline & $\begin{array}{l}\text { Per } \\
100 \mathrm{ml}\end{array}$ & $\begin{array}{l}\text { Per } \\
150 \mathrm{ml} / \mathrm{kg} \\
a \text { day }\end{array}$ & $\begin{array}{l}\text { Per } \\
100 \mathrm{ml}\end{array}$ & $\begin{array}{l}\text { Per } \\
180 \mathrm{ml} / \mathrm{kg} \\
\text { a day }\end{array}$ \\
\hline Energy (kJ) & 335 & 502 & 275 & 495 \\
\hline (kcal) & 79 & 119 & 65 & 117 \\
\hline Protein (g) & $2 \cdot 4$ & $3 \cdot 6$ & $1 \cdot 5$ & $2 \cdot 7$ \\
\hline Fat (g) & $5 \cdot 0$ & $7 \cdot 5$ & $3 \cdot 6$ & $6 \cdot 5$ \\
\hline Lactose (g) & $6 \cdot 6$ & $9 \cdot 9$ & $7 \cdot 2$ & 13 \\
\hline Sodium (mmol) & $2 \cdot 60$ & $3 \cdot 90$ & 0.65 & $1 \cdot 17$ \\
\hline Potassium (mmol) & $2 \cdot 43$ & $3 \cdot 65$ & $1 \cdot 43$ & $2 \cdot 57$ \\
\hline Chloride (mmol) & $2 \cdot 25$ & $3 \cdot 38$ & $1 \cdot 04$ & $1 \cdot 87$ \\
\hline Calcium (mmol) & $1 \cdot 67$ & $2 \cdot 51$ & $1 \cdot 1$ & $1 \cdot 98$ \\
\hline Magnesium (mmol) & 0.47 & $0 \cdot 71$ & $0 \cdot 22$ & 0.40 \\
\hline Phosphorus (mmol) & $1 \cdot 71$ & $2 \cdot 56$ & $1 \cdot 1$ & $1 \cdot 98$ \\
\hline
\end{tabular}

assisted ventilation, or xanthine medication during the study. Weight was recorded every other day, occipitofrontal circumference weekly, and length was measured at the beginning and end of the trial. The frequency and nature of stools were recorded. Plasma urea, sodium, potassium, and chloride concentrations together with haemoglobin and white cell counts were estimated twice weekly. Plasma calcium concentration was measured weekly as were urinary osmolality, sodium, and potassium concentration on a random urine sample.

\section{Results}

The clinical data for each group are shown in Table 2 , and the growth, haematological, and biochemical data in Table 3. Weight gain (Table 3) is expressed as $\mathrm{g} / \mathrm{kg}$ a day rather than as $\mathrm{g} /$ day as weight gain in utero in the last trimester is exponential ${ }^{10}$ and rate of gain of weight dependent on body weight. There was no significant difference between the proportion of small for gestational age infants in the groups (Fisher's exact test $P=0.485$ ). As the data were not normally distributed, medians and ranges are quoted and a nonparametric statistical methodnamely the Mann-Whitney $U$ test-was used to determine the significance of differences between the two groups in the trial.

Rates of gain of weight, length, and occipitofrontal circumference of both groups were similar and equalled intrauterine growth.11 12 No infant in either group developed diarrhoea, steatorrhoea, oedema, dehydration, patent ductus arteriosus, or necrotising enterocolitis. None became anaemic or leucopenic.

Plasma sodium, potassium, urea, and calcium concentrations were not significantly different and were within the normal range. The plasma chloride concentration of the Prematalac group was higher
Table 2 Clinical data

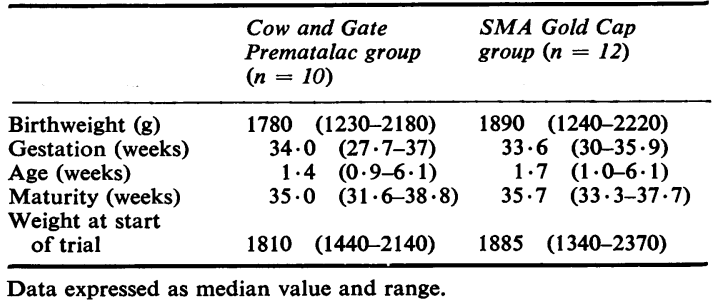

Table 3 Growth, haematological plasma, and urinary biochemistry

Cow and Gate
Prematalac

Prematalac

\begin{tabular}{|c|c|c|c|}
\hline \multicolumn{4}{|l|}{ Growth } \\
\hline Weight (g/kg a day) & $15 \cdot 2(9 \cdot 7-18 \cdot 4)$ & $13 \cdot 6(8 \cdot 1-19 \cdot 4)$ & NS \\
\hline Length $(\mathrm{cm} /$ day $)$ & $\begin{array}{l}0.16 \\
(-0.21-0.53)\end{array}$ & $\begin{array}{l}0.12 \\
(0.00-0.34)\end{array}$ & NS \\
\hline $\begin{array}{l}\text { Occipitofrontal } \\
\text { circumference } \\
\text { (cm/day) }\end{array}$ & $\begin{array}{l}0.14 \\
(0 \cdot 11-0.25)\end{array}$ & $\begin{array}{l}0 \cdot 18 \\
(0 \cdot 10-0 \cdot 25)\end{array}$ & NS \\
\hline \multicolumn{4}{|l|}{ Haematology } \\
\hline Haemoglobin (g/dl) & $\begin{array}{l}17 \cdot 6 \\
(8 \cdot 9-20 \cdot 7)\end{array}$ & $\begin{array}{l}14 \cdot 6 \\
(9 \cdot 0-19)\end{array}$ & NS \\
\hline White cell count & $\begin{array}{l}11 \cdot 0 \\
(8 \cdot 2-15 \cdot 2)\end{array}$ & $\begin{array}{l}11 \cdot 6 \\
(9 \cdot 3-15 \cdot 2)\end{array}$ & NS \\
\hline \multicolumn{4}{|l|}{ Plasma biochemistry } \\
\hline Urea (mmol/l) & $\begin{array}{l}2 \cdot 49 \\
(0 \cdot 9-3 \cdot 8)\end{array}$ & $\begin{array}{l}1 \cdot 52 \\
(0 \cdot 5-4 \cdot 1)\end{array}$ & NS \\
\hline Sodium (mmol/l) & $\begin{array}{l}140 \\
(134-144)\end{array}$ & $\begin{array}{l}137 \\
(133-139)\end{array}$ & NS \\
\hline Potassium (mmol/l) & $\begin{array}{l}4 \cdot 7 \\
(4 \cdot 1-5 \cdot 9)\end{array}$ & $\begin{array}{l}4 \cdot 8 \\
(4 \cdot 2-6 \cdot 0)\end{array}$ & NS \\
\hline Chloride (mmol/l) & $\begin{array}{l}107 \\
(102-108)\end{array}$ & $\begin{array}{l}103 \\
(97 \cdot 5-106)\end{array}$ & $<0.01$ \\
\hline Calcium (mmol/l) & $\begin{array}{l}2 \cdot 44 \\
(1 \cdot 79-2 \cdot 60)\end{array}$ & $\begin{array}{l}2 \cdot 49 \\
(2 \cdot 14-2 \cdot 74)\end{array}$ & NS \\
\hline \multicolumn{4}{|l|}{ Urinary biochemistry } \\
\hline Sodium (mmol/l) & $\begin{array}{l}28 \cdot 0 \\
(13-63)\end{array}$ & $\begin{array}{l}3 \cdot 9 \\
(0 \cdot 5-49)\end{array}$ & $<0.001$ \\
\hline Potassium (mmol/l) & $\begin{array}{l}26 \cdot 8 \\
(8-39)\end{array}$ & $\begin{array}{l}16 \cdot 8 \\
(4 \cdot 5-39)\end{array}$ & NS \\
\hline $\begin{array}{l}\text { Osmolality } \\
(\mathrm{mmol} / \mathrm{kg})\end{array}$ & $\begin{array}{l}192 \cdot 0 \\
(63-323)\end{array}$ & $\begin{array}{l}92 \cdot 5 \\
(63-195)\end{array}$ & $<0.005$ \\
\hline
\end{tabular}

Data expressed as median value and range.

$\mathrm{NS}=$ not significant, $\mathbf{P}>\mathbf{0 . 0 5}$.

Conversion: SI to traditional units-plasma urea: $1 \mathrm{mmol} / 1 \approx 6.02$ $\mathrm{mg} / 100 \mathrm{ml}$; plasma calcium: $1 \mathrm{mmol} / 1 \approx 4.0 \mathrm{mg} / 100 \mathrm{ml}$.

than the SMA group but both were within the normal range.

There was a marked difference in the composition of urine formed on the different milks (Table 3). Urinary sodium concentration of the majority of infants fed SMA Gold Cap was lower than 10 $\mathrm{mmol} / \mathrm{l}$ and in many cases lower than $5 \mathrm{mmol} / \mathrm{l}$; those fed Prematalac had a higher urinary sodium concentration, generally between 15 and $35 \mathrm{mmol} / \mathrm{l}$. Most infants fed SMA Gold Cap had a urinary osmolality less than $120 \mathrm{mmol} / \mathrm{kg}$ while the majority of the Prematalac group had a value between 120 and $240 \mathrm{mmol} / \mathrm{kg}$. In only one case did the urinary 
osmolality of an infant fed Prematalac exceed 300 $\mathrm{mmol} / \mathrm{kg}$. The urinary potassium concentration was similar in each group.

\section{Discussion}

The new formula (Cow and Gate Prematalac) differs in three important ways from formulae designed for use in term infants. Firstly, the higher energy density $(80 \mathrm{kcal} / 100 \mathrm{ml} ; 335 \mathrm{~kJ} / \mathrm{dl})$ provides sufficient energy for preterm infants to grow at intrauterine rates at a volume intake of $150 \mathrm{ml} / \mathrm{kg} \mathrm{a}$ day. ${ }^{3}$ Lower volume intakes are associated with an improved tolerance of feed and a lower incidence of patent ductus arteriosus ${ }^{4}$ and necrotising enterocolitis. ${ }^{5}$ The main energy source in the new formula is a mixture of butter fat and vegetable oil in a higher concentration than in standard formulae (Table 1). Secondly, the protein content is also higher. An intake of $150 \mathrm{ml} / \mathrm{kg}$ a day provides $3.6 \mathrm{~g}$ protein with a casein:whey ratio of 40:60. The protein concentration and composition are based on the recommendations of Senterre..$^{13} \mathrm{He}$ showed that an oral intake of $3 \cdot 5-4 \mathrm{~g} / \mathrm{kg}$ a day with the above casein :whey ratio was optimal for growth of preterm infants provided sufficient energy was available. ${ }^{13}$ Protein intakes within this range produce normal plasma urea levels, give a plasma amino acid profile similar to that of cord blood, and keep the dietary solute and acid loads well within the renal capacity for excretion. ${ }^{13}$ Thirdly, the sodium concentration has been increased to avoid late hyponatraemia (plasma sodium $<130 \mathrm{mmol} / \mathrm{l}$ ) which occurs in one-third to two-thirds of very low birthweight babies $(<1300 \mathrm{~g})$ fed low sodium milks. ${ }^{67}$ This can be slowly corrected if the dietary sodium is increased to $3 \mathrm{mmol} / \mathrm{kg}$ a day. ${ }^{6}$ Late hyponatraemia occurs if sodium intake is below that required for growth $(1 \cdot 2$ $\left.\mathrm{mmol} / \mathrm{kg} \mathrm{a} \mathrm{day}{ }^{10}\right)$ and for loss in the urine. Immature renal function in very low birthweight babies leads to a high urinary sodium loss even in the presence of hyponatraemia. ${ }^{7}$ Leake $^{8}$ has estimated the urinary sodium loss in these infants to be $2.5 \mathrm{mmol} / \mathrm{kg} \mathrm{a}$ day. Sick preterm infants and those on xanthine derivatives for apnoea have even higher urinary sodium losses. ${ }^{8}$ The new formula provides $4 \mathrm{mmol} / \mathrm{kg}$ a day sodium to meet the normal requirement of very low birthweight babies and to allow extra sodium for those who are unwell or being treated with xanthine derivatives.

The clinical course of infants fed the new formula at $150 \mathrm{ml} / \mathrm{kg}$ a day was identical with that of infants fed the standard formula at $180 \mathrm{ml} / \mathrm{kg}$ a day and no infant had any complication. Both groups gained weight, length, and head circumference at intrauterine rates. The main advantage of the new formula was growth at these rates with an intake of $30 \mathrm{ml} / \mathrm{kg}$ a day less than required with the standard formula. This has several advantages when milk is being introduced gradually to the preterm infant; firstly, a full energy intake is achieved earlier because of the lower volume intake required; secondly, infants who can tolerate only low volume feeding because of intercurrent illness will be better nourished.

Infants fed the new formula and the standard formula had plasma sodium, potassium, chloride, calcium, and urea levels within the normal range. In particular none fed the new formula developed hypernatraemia and none fed the standard formula developed hyponatraemia (Table 3). The latter result is not unexpected since the infants fed standard milk formula were more mature than those in whom late hyponatraemia has been reported ${ }^{67}$ (Table 2). Sodium content of the standard milk formula will match the $1.2 \mathrm{mmol} / \mathrm{kg}$ a day required for growth ${ }^{10}$ provided that it is fed at $180 \mathrm{ml} / \mathrm{kg}$ a day (Table 1) and that the infant's renal tubular function is sufficiently mature maximally to reabsorb sodium. The very low sodium concentration in the urine of this group (Table 3) shows that this degree of renal sodium reabsorption has been achieved. The higher urinary sodium found in the Prematalac group means that the new formula provides a margin of safety to prevent late hyponatraemia in very low birthweight babies.

Urinary osmolality of the group fed the new formula was higher than that fed the standard milk formula, no doubt reflecting the higher sodium and protein loads and the lower fluid intake of the new formula group. The range of osmolality found in infants fed the new formula was within the concentrating ability of the very preterm infant ${ }^{8}$ and indicates that adequate fluid was provided to meet the obligatory renal solute loss.

\section{Conclusion}

The new formula fed at $150 \mathrm{ml} / \mathrm{kg}$ a day leads to growth at intrauterine rates. The increased sodium concentration is sufficient for the needs of very preterm infants ${ }^{6} 7$ and although it is greater than the requirement of more mature infants the excess can safely be excreted in the urine. The new formula appears to be a suitable milk for all babies of low birthweight, but further information is needed for the infant of very low birthweight, particularly if he is sick.

We thank the nursing and medical staff of the Special Care Baby Unit and Mrs P Dodds and Dr Pennock of the Department of Biochemistry Bristol, 
Maternity Hospital, for assistance; A F Morris, Department of Public Health, University of Bristol, for statistical advice and help; Dr P M Dunn for allowing his patients to be included in the study; Miss J A Hughes and Mrs V Libbiter for the preparation of the manuscript.

\section{References}

1 Burman D. Nutrition in early childhood. In: McLaren D S, Burman D, eds. Textbook of paediatric nutrition. Edinburgh: Churchill Livingstone, 1976: 46-75.

2 Jonxis J H P. Special problems arising in the nutrition of very small prematures and their subsequent growth. In: Wilkinson A W, ed. Early nutrition and later development. Tunbridge Wells: Pitman Medical, 1976: 79-91.

3 American Academy of Pediatrics Committee on Nutrition. Nutritional needs of low-birth weight infants. Pediatrics 1977; 60: 519-30.

4 Bell E F, Warburton D, Stonestreet B S, Oh W. Randomized trial comparing high (HV) and low-volume (LV) maintenance fluid administration in low-birth-weight infants (abstract). Pediatr Res 1979; 13: 489.

5 Bell E F, Warburton D, Stonestreet B S, Oh W. Letter: High-volume fluid intake predisposes premature infants to necrotising enterocolitis. Lancet 1979 ; ii: 90.

- Roy R N, Chance G W, Radde I C, Hill D E, Willis D M, Sheepers J. Late hyponatremia in very low birth weight infants ( $<1.3$ kilograms). Pediatr Res 1976; 10: 526-31.
Day G M, Radde I C, Balfe J W, Chance G W. Electrolyte abnormalities in very low birthweight infants. Pediatr Res 1976; 10: 522-6.

${ }^{8}$ Leake R D. Perinatal nephrobiology: a developmental perspective. Clin Perinatol 1977; 4: 321-49.

9 Gairdner D, Pearson J. A growth chart for premature and other infants. Arch Dis Child 1971; 46: 783-7.

10 Shaw J C L. Parenteral nutrition in the management of sick low birthweight infants. Pediatr Clin North Am 1973; 20: 333-58.

11 Usher R, McLean F. Intrauterine growth of liveborn Caucasian infants at sea level: standards obtained from measurements in 7 dimensions of infants born between 25 and 44 weeks of gestation. J Pediatr 1969; 74: 901-10.

12 Lubchenco L O, Hansman C, Boyd E. Intrauterine growth in length and head circumference as estimated from live births at gestational ages from 26-42 weeks. Pediatrics 1966; 37: 403-8.

13 Senterre J. Nitrogen balances and protein requirements of preterm infants. In: Visser $\mathrm{H} \mathrm{K} \mathrm{A,} \mathrm{ed.} \mathrm{Nutrition} \mathrm{and}$ metabolism of the fetus and infant. The Hague: Nijhoff, 1979: 195-212.

Correspondence to Dr T J French, Department of Paediatrics, Musgrove Park Hospital, Taunton, Somerset PA1 5DA.

Received 25 January 1982 